Sains Malaysiana 47(1)(2018): 77-84

http://dx.doi.org/10.17576/jsm-2018-4701-09

\title{
Evaluation of Climate Variability Performances using Statistical Climate Models
}

(Penilaian Prestasi Kebolehubahan Iklim menggunakan Model Statistik Iklim)

\author{
NURUL NADRAH AQILAH TUKIMAT*, AHMAD SAIFUdDIN OTHMAN, \\ SAFFUAN WAN AHMAD \& KHAIRUNISA MUTHUSAMY
}

\begin{abstract}
Uncertainty of the climates nowadays bring the crucial calamities problems especially at unexpected areas and in anytime. Thus, the projection of climate variability becomes significant information especially in the designing, planning and managing of water resources and hydrological systems. Numerous climate models with varies methods and purposes have been developed to generate the local weather scenarios with considered the greenhouse gasses (GHGs) effect provided by General Circulation Models (GCMS). However, the accuracy and suitability of each climate models are depending on the atmospheric characters' selection and the variables consideration to form the statistical equation of local-global weather relationship. In this study, there are two well-known statistical climate models were considered; Lars-WG and SDSM models represent for the regression and weather typing methods, respectively. The main aim was to evaluate the performances among these climate models suit for the Pahang climate variability for the upcoming year $\Delta 2050$. The findings proved the Lars-WG as a reliable climate modelling with undemanding data sources and use simpler analysis method compared to the SDSM. It is able to produce better rainfall simulated results with lesser \%MAE and higher $R$ value close to 1.0. However, the SDSM lead in the temperature simulation with considered the most influenced meteorological parameters in the analysis. In year $\Delta 2050$, the temperature is expected to rise achieving $35^{\circ} \mathrm{C}$. The rainfall projection results provided by these models are not consistent whereby it is expecting to increase $2.6 \%$ by SDSM and reduce $1.0 \%$ by Lars-WG from the historical trend and concentrated on Nov.
\end{abstract}

Keywords: Climate performance; climate prediction; lars-wg; Pahang climate; SDSM

\section{ABSTRAK}

Ketidaktentuan cuaca kini membawa kepada bencana alam yang dahsyat terutama kepada kawasan yang tidak dijangka dan dalam masa yang tidak menentu. Oleh itu, unjuran perubahan iklim menjadi maklumat penting terutama dalam reka bentuk, perancangan dan pengurusan sumber air dan sistem hidro. Pelbagai model iklim dengan metod dan tujuan yang berbeza telah dibangunkan untuk menjana senario iklim setempat dengan mengambil kira kesan gas rumah hijau yang dibekalkan oleh Model Sikulasi Umum (GCMs). Namun, ketepatan dan keseimbangan setiap model iklim adalah bergantung kepada pemilihan ciri atmosfera dan variasi yang digunakan untuk membentuk persamaan statistik bagi hubungan cuaca setempat-global. Dalam kajian ini, 2 model iklim statistik telah digunakan; Model Lars-WG dan Model SDSM mewakili kaedah regresi dan kaedah cuaca penaipan. Tujuan utama adalah untuk menilai prestasi antara model yang bersesuaian dengan kebolehubahan iklim di Pahang pada tahun 2050. Keputusan telah menunjukkan bahawa Lars-WG sebagai model iklim yang boleh dipercayai tanpa memerlukan sumber data yang banyak dan menggunakan kaedah yang lebih mudah berbanding SDSM. Ia juga dapat menghasilkan keputusan simulasi yang lebih baik dengan $\%$ MAE yang lebih sedikit dan nilai $R$ menghampiri 1.0. Walau bagaimanapun, SDSM mengungguli bagi simulasi suhu dengan mengambil kira parameter meteorologi yang paling berpengaruh dalam analisis. Keputusan unjuran iklim menunjukkan bahawa suhu dianggarkan akan meningkat sehingga mencecah $35^{\circ} \mathrm{C}$. Walau bagaimanapun, model tersebut menghasilkan laporan unjuran hujan yang tidak tekal dengan hujan tahunan dianggarkan meningkat sebanyak $2.6 \%$ oleh SDSM dan berkurangan sebanyak $1.0 \%$ oleh Lars-WG daripada sejarah aliran dengan anggaran bahawa hujan lebat tertumpu pada bulan Nov.

Kata kunci: Iklim Pahang; jangkaan iklim; lars-wg; prestasi iklim; SDSM

\section{INTRODUCTION}

Extreme changes of climate nowadays become chaos and can be horrifying at anywhere in anytime. Ismail et al. (2014) proved the ozone concentration in the atmospheric system is increasing year by year due to the increment of anthropogenic sources contributed to the greenhouse gasses (GHGs) contaminant in the atmospheric circulation system. Kwan et al. (2013) proved the elevated of GHGs year by year may bring the warm temperature extreme at night as compared to the warm day especially in the East- 
coast Malaysia. Thus, the changes pattern in the spatial and temporal variability is significantly to be forecasted using hydrological modeling (Mohsen et al. 2014).

In recent years, Malaysia had been experienced with serious calamities events whereby the strength of the calamities influenced by the monsoons trend and GHGs level. Normally, Northeast-monsoon produces huge impact to the country and society due to the heavy rainfall and followed by flood. During this monsoon, the cyclone vortices are formed when convergence interaction is existed between strong cold air with low pressure atmospheric system. It is resulting to the strong wind, sea level rises, heavy rainfall in very short spell and overflow of the rivers. This situation becomes worst when the excessive water receded very slow and inundated at the nearest residential areas which were resulted to the properties destructed, food scarcity, and economy losses in million ringgits. According to the Meteorological Department Malaysia report in year 2014 (MDM 2014), the total monthly rainfall at that critical time achieved $1200 \mathrm{~mm} / \mathrm{month}$, $60 \%$ greater than the normal monthly rainfall. Even the calamities were affected by the natural of cyclical monsoons, but it could be extremely affected by the climate change impact.

Thus, the long term climatic information becomes significant data input to plan and manage the water resources and hydrological system efficiently. The main purpose was to look forward the changes pattern of climate trend affected by the greenhouse emissions and the implication to the hydrological system. The statistical downscaling (SD) employs a statistical relationship between the large scale climatic characteristics with the local climatic variations that representing in the statistical equations. It is considered by many researchers because the model applied simpler statistical equation that is easier to understand the relationship pattern between local weather and global climate. Besides, the model does not require high computational demand to view the simulation result because the output is presented in the finer resolutions. Thus, it could reduce the total cost of the project but at the same time has higher ability to produce better climate simulation (Chen et al. 2012; Chu et al. 2009; Hamidon et al. 2015; Hashmi et al. 2011; Tukimat \& Harun 2013). The SD classifies into 3 groups based on the parameters consideration and statistical methods in presenting the global atmospheric and local climate relationships. There are regression methods (Statistical Downscaling Model, SDSM), weather typing scheme and weather generator (Long Ashton Research Station Weather Generator - LarsWG). The SDSM interprets the predictand (local weather trend) and predictor (GCMs-scale) relationship using multiple regression techniques. Meanwhile, Lars-WG model uses probability distribution functions based on the wet and dry length records to generate the climatic changes and variability (Semenov 2002). Both models are the most popular and recently applied among researchers due to its reliability and consistency (Hassan \& Harun 2012; Sharma et al. 2010). The weather typing method was not considered in this study due to the inconsistent connection between changes frequency of weather pattern with the host GCM output (Wilby \& Dawson 2007).

The selection of the influenced atmospheric characters, grid locations and scenarios consistency can be as basis to control the accuracy and reliability of the projected results. For the predictors selection, some behavior should be considered there are should be reliable to simulate by GCM, readily available from archives of GCM output and strongly correlated with the surface variable of interest (Wilby et al. 1999). Even both models use statistical concept, however, each model tend to produce different performances and reliability depending on the variables selection and the location of local site study. Hassan et al. (2014) in their study reported that the SDSM model had better performances during calibration and validation processes compared to the Lars-WG but produced similar trend in the future year. Supported by Hashmi et al. (2011) stated the SDSM performed well in simulation with very close GEV distribution to the historical record. It is contrast to the findings from Lee and Lam (2004) that showed the Lars-WG model produced better performances in generating daily precipitation than SDSM model but unreliable in daily temperature extreme. However, in 2015, Lee and Lam agreed the SDSM model is more capable to describe the climatic changes in an extreme condition compared to the Lars-WG model. The performances of each models are varies depending on the local influence factors in constructing the climate projection trend suit to the site conditions. The best climate model to present Pahang climate variability is still chaos and unknown because impropriate selection of climate models will produce unreliable projected results. The main aim of this paper were to evaluate the performances of Lars-WG and SDSM model as reliable climatic model for Pahang state and to predict the future changes of temperature and rainfall trends for year $\Delta 2050$ using SDSM and Lars-WG models.

\section{SITE OF STUDY}

The study was conducted at Pahang state based on the historical extreme flood events in the recent years back. It is located at east coast of peninsular Malaysia near to the South China Sea. The rainfall distributions at this region is influenced by the wind direction and 2 monsoons pattern known as Northeast (Oct - Mar) and Southwest (Jun - Aug) monsoons. The land area is $35,965 \mathrm{~km}^{2}$ and has 2 main river basins; Kuantan river and Pahang river basins. The annual rainfall is $2400 \mathrm{~mm}$ /year with average temperature of $28^{\circ} \mathrm{C}$. The highest and lowest rainfall intensity is focused on Dec and Jan, respectively. The average wind speed is 5 mph with the relative humidity of $85 \%$. Twelve (12) rainfall stations at surrounding Pahang state were selected based on the availability of 30 years length data records as shown in Figure 1 meanwhile Figure 2 shows the monthly weather trend at the region. The lists of rainfall stations are Kuala Reman (KR), Keretapi Kerambit (KK), Kechau (Kec), Kuala Bera (KB), Kg. Serambi (KgSe), Kg. Salong (KgSa), Kg. 
Temai Hilir (KgTH), Kg Jami (KgJ), Janda Baik (JB), Kg Manchis (KgM), Palas (Pal), Bhg. Selatan (Sel).

\section{METHODS}

\section{STATISTICAL DOWNSCALING MODEL (SDSM)}

The SDSM model was chosen to simulate future rainfall at the pointed grid box. This model is widely used in the context of hydrological issue due to climate scenarios because it provides station scale climate information from grid resolution GCM-scale as input based on

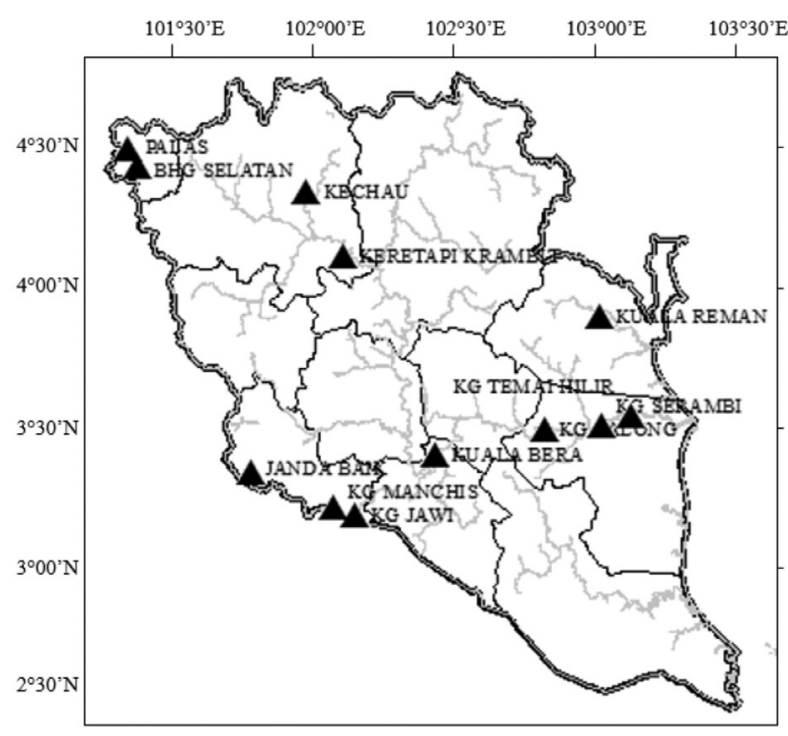

FIGURE 1. Topography of Pahang state, Malaysia

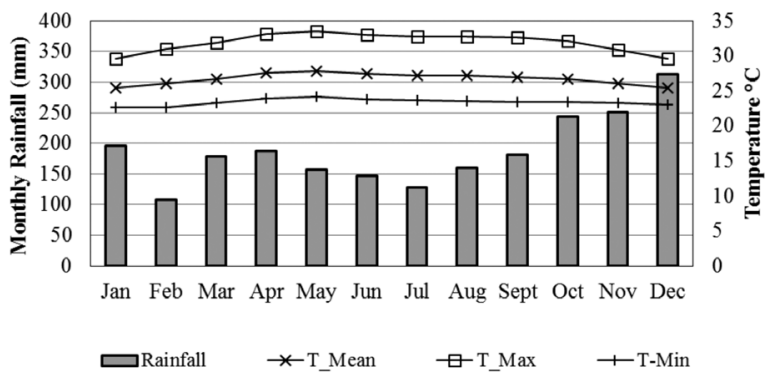

FIGURE 2. Historical monthly weather distribution pattern at Pahang state multiple regression techniques (Wilby \& Dawson 2007). These regressions emerged from the empirical statistical relationship between atmospheric circulation pattern (predictors) and local scale parameters (predictand). Besides, the simplicity and computationally undemanding of SDSM tools made it acceptable and recognizable in terms of climate model projection. Daily rainfall data and daily atmospheric predictors from NCEP reanalysis data calibrates and validates in the period year 1984 - 2013 to develop the downscaling relationship. Then, the GCMs data are utilized to generate future trend for interval year periods of $\Delta 2050$. The A2 scenario chosen for this study provides an upper bound on future emissions and it is selected from an impacts-and-adaptation point of view; if it is adaptable to large climate change, it will have no problem with smaller climate change and lower end scenario, although low emissions scenario gives less information from this point of view. As stated by Tukimat and Alias (2016), the A2 scenario has more potential to develop bigger impacts of global warming compared to other emission groups.

\section{LARS-WG MODEL}

Lars-WG is one of the weather generator type to simulate weather stochastic based on the statistical characteristics of the local weather. The model uses daily weather time series to determine a set of probability distribution parameters and next will be used as a predictor agent to generate the synthetic weather time-series in the long term. The weather is classified into 2 categories there are wet and dry days depending on the daily rainfall amount. Wet and dry length records are used to determine the rainfall occurrence and solar radiation using semi-empirical distributions (EMP) for each month. EMP is a histogram with 10 different intervals $\left(a_{i-1}, a_{i}\right)$ where $a_{i-1}<a_{i}$ and $h$ is the number of the events from observed data in the $i$-th interval. Meanwhile for the temperature simulation, the normal distribution is used for the temperature variables with the mean and standard deviation varying daily according to finite Fourier series of order three (Semenov 2002).

In this study, mean absolute error (MAE) and correlation value $(\mathrm{R})$ have been applied in measuring and comparing the performances of each model. Table 1 shows the equation involved in this study where $X_{o b s}$ refers to the $\mathrm{i}^{\text {th }}$ month observed data, $X_{e s t}$ is the $\mathrm{i}^{\text {th }}$ month estimated data, $\mathrm{n}$ is the number of data.

TABLE 1. Equation for statistical analysis

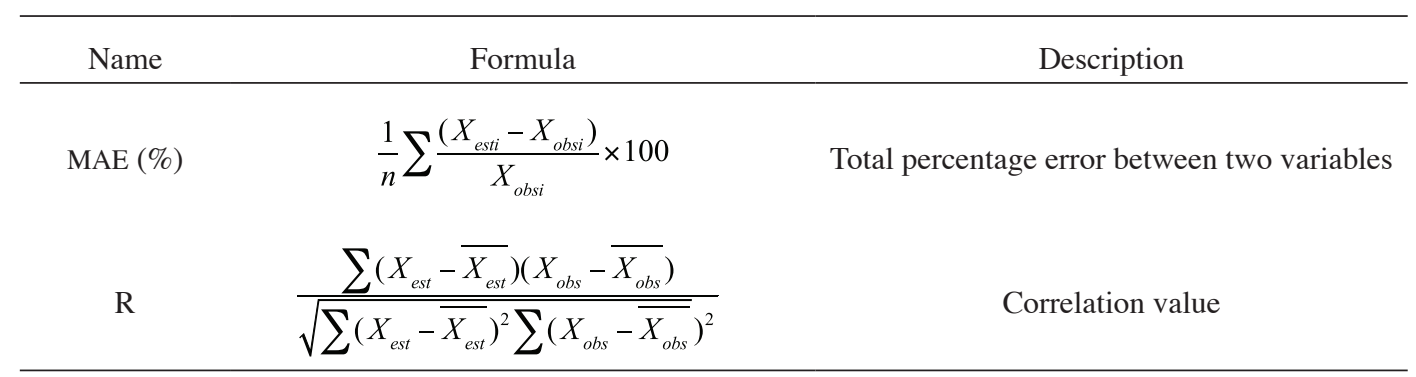




\section{RESULTS AND DISCUSSION}

Variables are very important data input in developing the climate relationship. The consideration of variables is depending on the local weather behavior. In this case study, Lars-WG and SDSM models have been applied to generate the local climate trend in the upcoming year.

The analysis showed that both models require similar variables as data input there are daily local weather (as predictand) and GCMs parameters (as predictor). The contrast between these models is in term of the predictor selection. In the Lars-WG, the selection of predictors is controlled by the model however in the SDSM, the user is able to choose at least 5 predictors based on the multiple correlation values. The predictand-predictor relationship that produce greater correlation values will be selected as predictor for this region. It is significant to show how strong the predictor's behavior is affected to the formation of local weather. Thus, the accuracy and reliability of the projection results is controlled by the strong bond among the predictors and predictand.

Based on the output, the Lars-WG is able to produce more meteorological output than the SDSM even use the same data input as shown in Figure 3. With limited data input, the model is able to generate the temperature and potential of evapotranspiration (PET) for each local station. It is not possible in the Lars-WG because the temperature estimation is based on the daily means and daily standard deviations on the dry and wet length records. Meanwhile, the PET was determined using Priestly-Taylor method under radiation-based methods whereby the PET value is depending on the long-wave radiation and temperature in the calculation. The result was suspicious because the local radiation was not provided in this study. Besides, the Priestly-Taylor method has potential to produce bigger biases rather than others radiation-based method (Tukimat et al. 2012).

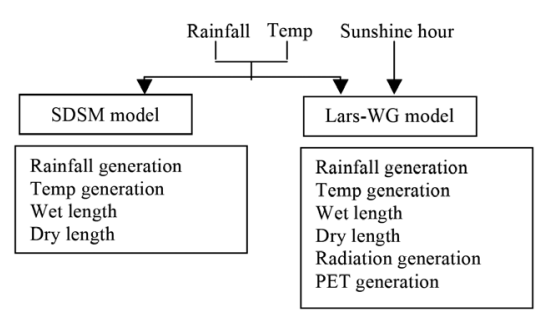

FIGURE 3. Summary of data input and output of models

\section{PERFORMANCES COMPARISON FOR CLIMATE SIMULATED RESULT}

The calibration and validation processes are necessity to ensure the accuracy and reliability of the projected results. The goal is to identify the fundamental rules and the predictand-predictors relationships are able to adequate as original data. During calibration (1984-1995) and validation (1996-2008) processes, each model used different approaches in controlling the accuracy of the model output.

For Lars-WG, the accuracy is based on the KolmogorovSmirnov (K-S) test and p-value for the calibrated and validated results. The good analysis is considered when the $\mathrm{K}-\mathrm{S}$ value is less than 1 and $\mathrm{p}$-value is closed to 1 . In this study, the performances of calibration and validation results produced by Lars-WG as shown in Table 2. Contrast to the SDSM, the reliability and robustness of the simulated results is referred to the performances of selected atmospheric variables to the local weather trend. The selection of predictors for each weather station was different as shown in Table 3. Based on the correlation results, three predictors there are surface meridional velocity (p_v), relative humidity at $850 \mathrm{hpa}(\mathrm{p} 850)$ and near surface relative humidity (rhum) are well correlated with all the local weather stations with $>0.5$ of the correlation value. These atmospheric parameters are reliable and suitable

TABLE 2. K-S test and p-value results for 12 stations

\begin{tabular}{lccccl}
\hline & \multicolumn{2}{c}{ Calibration } & \multicolumn{2}{c}{ Validation } & \\
\cline { 2 - 4 } Station Name & KS statistic & p-value & KS statistic & p-value & \\
\hline KR & 0.07 & 1.00 & 0.07 & 1.00 & Satisfactory \\
KK & 0.10 & 0.99 & 0.08 & 1.00 & Satisfactory \\
Kec & 0.10 & 0.99 & 0.10 & 1.00 & Satisfactory \\
KB & 0.10 & 0.99 & 0.09 & 0.99 & Satisfactory \\
$\mathrm{KgSe}$ & 0.09 & 1.00 & 0.10 & 0.99 & Satisfactory \\
$\mathrm{KgSa}$ & 0.08 & 1.00 & 0.09 & 0.99 & Satisfactory \\
$\mathrm{KgTH}$ & 0.08 & 1.00 & 0.08 & 1.00 & Satisfactory \\
$\mathrm{KgJ}$ & 0.08 & 0.98 & 0.09 & 1.00 & Satisfactory \\
$\mathrm{JB}$ & 0.09 & 0.99 & 0.10 & 0.99 & Satisfactory \\
$\mathrm{KgM}$ & 0.07 & 1.00 & 0.09 & 1.00 & Satisfactory \\
$\mathrm{Pal}$ & 0.10 & 0.98 & 0.10 & 0.98 & Satisfactory \\
$\mathrm{Sel}$ & 0.09 & 1.00 & 0.10 & 0.95 & Satisfactory \\
\hline
\end{tabular}


TABLE 3. Predictor selection for temperature and rainfall

\begin{tabular}{|c|c|c|c|c|c|c|c|c|c|c|c|c|c|}
\hline & $\mathrm{KgJ}$ & $\mathrm{KgM}$ & JB & $\mathrm{KB}$ & $\mathrm{KgSa}$ & $\mathrm{KgSe}$ & $\mathrm{KgTH}$ & KR & KK & $\mathrm{Kec}$ & Sel & Pal & Temp \\
\hline p_u & & I & & & & & I & I & & & & & \\
\hline p_v & I & 1 & I & 1 & I & I & & & I & & I & I & \\
\hline p_z & & & & & & I & I & I & & & & & I \\
\hline p5_u & & & & I & & & & I & I & & I & I & \\
\hline p500 & & & & & & I & & & & I & & & I \\
\hline p8_u & I & I & I & & & & & & I & & & & \\
\hline p850 & & & & & & & & & & I & & & \\
\hline r500 & & & & & I & & I & & & & I & & I \\
\hline r850 & I & I & I & I & I & I & I & I & I & I & I & I & I \\
\hline rhum & I & I & & I & I & I & I & I & I & I & I & I & \\
\hline shum & I & & I & I & I & & & & & & & I & \\
\hline tmean & & & & & & & & & & I & & & I \\
\hline
\end{tabular}

for the local weather trend because of the study location nearest to the equator and expose to the high humidity and wind.

Figure 4 and Table 4 present the performances comparison of the simulated results produced from Lars-
WG and SDSM models with the historical data. Generally, all models are performed well and produced quite similar to the historical monthly pattern. For the temperature simulation, SDSM was successfully to generate the temperature results in terms of maximum (Tmax), mean
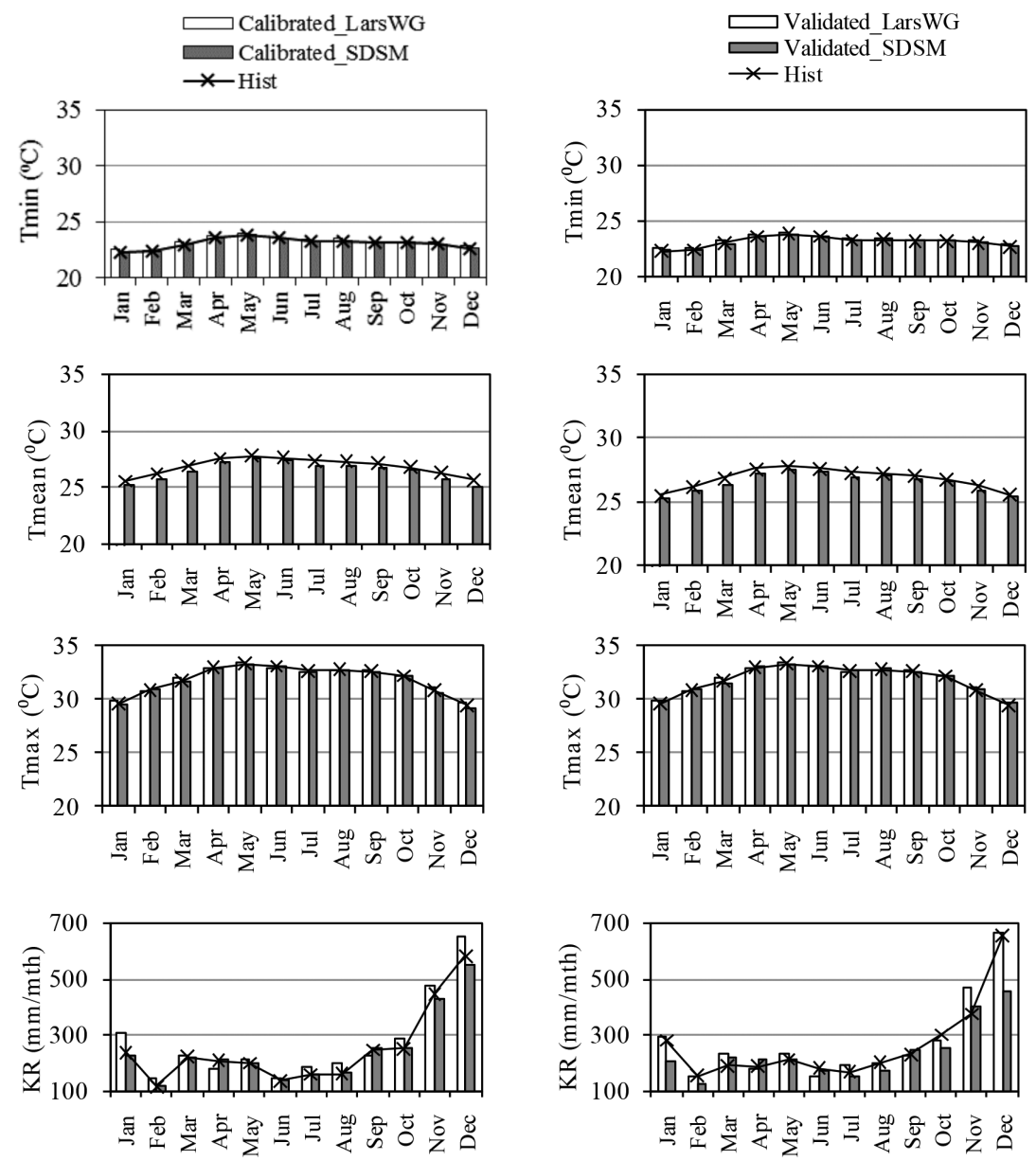

FIGURE 4. Calibrated and validated performances of SDSM and

Lars-WG compared with historical data 
TABLE 4. Statistical analysis comparison for rainfall and temperature simulated by SDSM and Lars-WG model

\begin{tabular}{llcccccccccccc}
\hline \multicolumn{2}{c}{ Station rainfall } & $\mathrm{KgJ}$ & $\mathrm{KgM}$ & $\mathrm{JB}$ & $\mathrm{KB}$ & $\mathrm{KgSa}$ & $\mathrm{KgSe}$ & $\mathrm{TH}$ & $\mathrm{KR}$ & $\mathrm{KK}$ & $\mathrm{Kec}$ & Sel & Pal \\
\hline \multirow{2}{*}{ SDSM } & $\mathrm{R}$ & 0.99 & 0.99 & 0.99 & 0.80 & 0.99 & 0.99 & 0.99 & 0.99 & 0.99 & 0.84 & 0.99 & 0.99 \\
& MAE $(\%)$ & 20.0 & 13.0 & 29.2 & 19.1 & 28.7 & 27.1 & 29.6 & 21.6 & 28.8 & 24.1 & 25.2 & 21.8 \\
\multirow{2}{*}{ Lars-WG } & $\mathrm{R}$ & 0.93 & 0.98 & 0.97 & 0.96 & 0.92 & 0.99 & 0.97 & 0.99 & 0.95 & 0.97 & 0.99 & 0.97 \\
& MAE $(\%)$ & 8.2 & 9.5 & 13.8 & 10.4 & 15.7 & 10.9 & 9.9 & 10.2 & 14.0 & 10.0 & 9.6 & 9.2 \\
\hline
\end{tabular}

\begin{tabular}{llccc}
\hline & & Tmax & Tmean & Tmin \\
\hline \multirow{2}{*}{ SDSM } & R & 0.99 & 0.99 & 1.0 \\
& MAE $(\%)$ & 0.39 & 1.24 & 0.28 \\
\multirow{2}{*}{ Lars-WG } & R & 0.99 & Nil & 0.99 \\
& MAE $(\%)$ & 0.44 & Nil & 0.77 \\
\hline
\end{tabular}

(Tmean) and minimum (Tmin). However, the Lars-WG model only able to produce the Tmax and Tmin with assume Tmean is average from both results. The Lars-WG is also able to generate the temperature trend for each 12 locations of study area with only based on the Kuantan meteorological station.

However, the results are unacceptable and unreliable with the reasons of different land use, contour and meteorological effect for each station. Based on the statistical analysis, both models are successful to produce very strong correlation value closed to 1 with MAE is less than $1.3 \%$. Comparing SDSM and Lars-WG performances for the temperature simulation, it is clearly show that the SDSM performed well with lower \%MAE than the Lars-WG.

Meanwhile, the Lars-WG has better performances than SDSM model in the rainfall simulated results with lesser MAE and higher of $\mathrm{R}$ values. The error from SDSM model is might affected by the combination of predictor selections that gives huge influence to the rainfall pattern. As mentioned by Tukimat and Harun, 2013 where the prediction of rainfall is very sensitive to the atmospheric characteristics and might have different influence factors for each location. However, the simulated results from SDSM model are considered acceptable for this study because the error is less than $30 \%$ with the $\mathrm{R}$ value is closed to 1.0 .

\section{COMPARISON OF RAINFALL AND TEMPERATURE TREND IN YEAR $\triangle 2050$}

Figure 5 is the projected results of rainfall pattern for the interval year of $\Delta 2050$ using SDSM and Lars-WG models. Based on the results, the rainfall pattern is distributing non-uniformly at the whole area of Pahang state whereby several locations might receive higher rainfall intensity compared to other areas. In year $\Delta 2050$, most of the areas are expected to receive lesser rainfall amount compared to the historical record except at Bera and Bentung districts. However, the projection of rainfall amount using 2 climate models is slightly different and inconsistent.

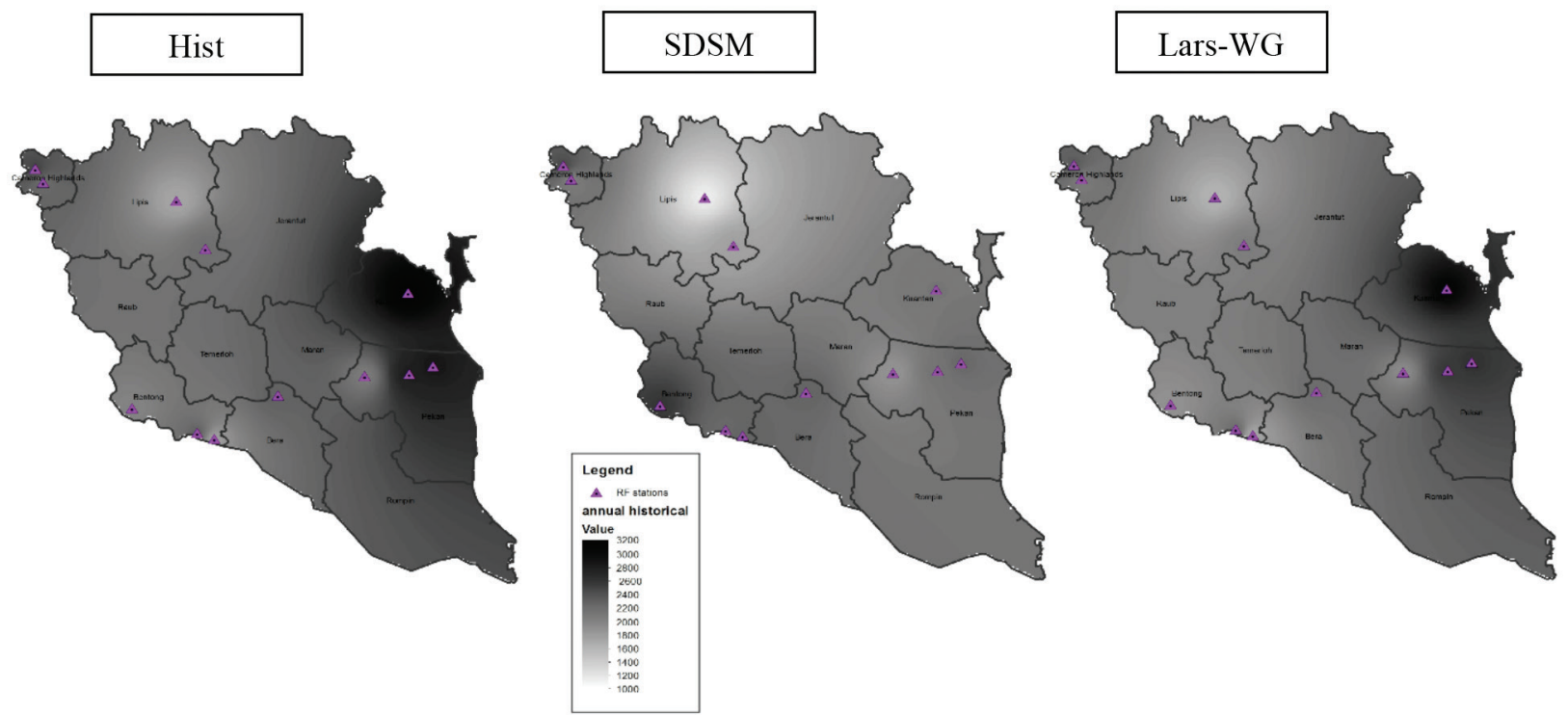




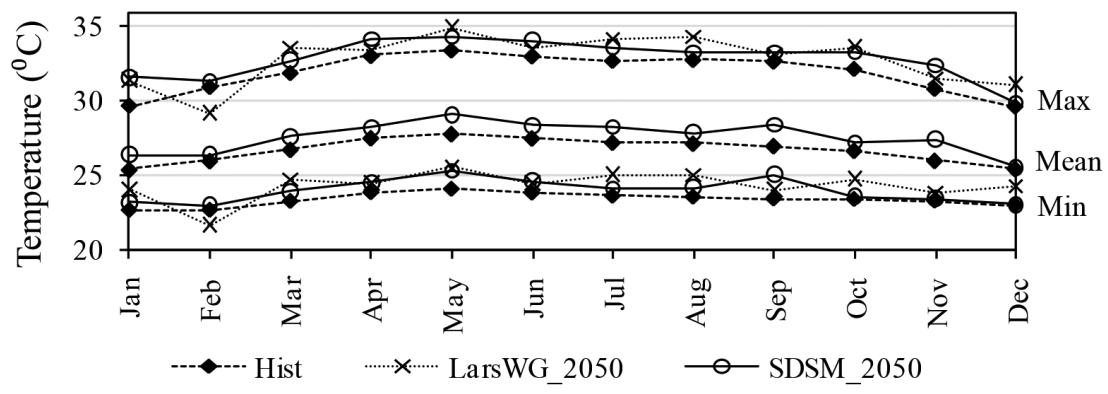

FIGURE 6. Comparison of temperature projected result in year $\Delta 205$

SDSM projection results show that 5 locations potentially to receive higher annual rainfall than the historical there are $\mathrm{KB}, \mathrm{KgJ}, \mathrm{JB}, \mathrm{Pal}$ and $\mathrm{KgTH}$ with increment of $2 \%$ to $35 \%$. The heaviest rainfall is predicted focused on these 2 potential districts; Cameron Highland and Bentong with the annual rainfall is expected to reach $>3000 \mathrm{~mm}$. In average, the annual rainfall of Pahang state is predicted to raise $2.6 \%$ from the historical record.

Meanwhile Lars-WG model shows only 2 locations are predicted to receive higher rainfall intensity than the historical there are $\mathrm{KB}$ and JB with $+18 \%$ to $+35 \%$. The heaviest rainfall is expected to disperse around Kuantan district similar to the historical record. The annual rainfall of Pahang state using this model is estimated to reduce about $1.0 \%$ from the historical. However, both models agree that November and February are the critical months who receive the highest and lowest rainfall through a year, respectively. Contrast to the projected temperature as shown in Figure 6, both models predicted similar results. The increment is expected to reach $4 \%$ during interval year of $\Delta 2050$. The highest temperature is focused on May with the temperature reading is achieving $35^{\circ} \mathrm{C}$. February is the lowest temperature reading and estimated to drop to $21^{\circ} \mathrm{C}$, whereby $4 \%$ lower than the historical record. Even the Lars-WG model only able to produce the max and min temperature, however it is sufficient as data input for rainfall-runoff modeling.

\section{CONCLUSION}

The performances of Lars-WG and SDSM model are evaluated in this study based on the variables demanding, calibrated and validated performances and climate prediction for the interval year of $\Delta 2050$. The study was focused on Pahang state, Malaysia where the climate pattern is influenced by 2 monsoons. Thirty years length historical records were used to calibrate, validate and generate the future changes trend with consider the atmospheric changes due to greenhouse gases level.

In term of the parameters requirement, the Lars-WG is undemanding climatic model in term of data input and simple analysis compared to the SDSM model which requires complex procedure. Furthermore, the Lars-WG model is able to provide more climatic and meteorological information such as rainfall simulation, temperature simulation, wet and dry length, solar radiations and PET value. In the calibration and validation processes, the SDSM performed well for the temperature simulations with lesser \% MAE and R value close to 1 but not in the rainfall simulation. The bigger error in the simulated results might affected by the predictor selection that gives huge influence to the rainfall pattern.

In the climate projection of year $\Delta 2050$, both models provide consistent projected result in the temperature but different climatic variability in the rainfall trend. It is expected to rise up to $35^{\circ} \mathrm{C}$ on May in the future year. The average annual rainfall is predicted to increase $2.6 \%$ using SDSM model, however, it is expected to reduce $1.0 \%$ by using Lars-WG model. Five areas that expected to receive higher rainfall amount than the historical record there are $\mathrm{KB}, \mathrm{KgJ}$, JB, Pal, and. However, both models agree that November and February are the critical months who receive the highest and lowest rainfall through a year, respectively.

\section{ACKNOWLEDGEMENTS}

This research is supported by the Meteorological Department Malaysia (MDM), Drainage and Irrigation Department (DID) and the Ministry of Higher Education (MHE) for grant vote RDU150113.

\section{REFERENCES}

Chen, H., Guo, J., Zhang, Z. \& Xu, C. 2012. Prediction of temperature and precipitation in Sudan and South Sudan by using LARS-WG in future. Theoretical and Applied Climatology 113(3-4): 363-375. doi:10.1007/s00704-0120793-9.

Chu, J.T., Xia, J., Xu, C.Y. \& Singh, V.P. 2009. Statistical downscaling of daily mean temperature, pan evaporation, and precipitation for climate change scenarios in Haihe River, China. Theoretical and Applied Climatology 99(1-2): 149-161. doi:10.1007/s00704-009-0129-6.

Hashmi, M.Z., Shamseldin, A.Y. \& Melville, B.W. 2011 Statistical downscaling of watershed precipitation using gene expression programming (GEP). Environmental Modeling Software 26(12): 1639-1646. doi:10.1016/j. envsoft.2011.07.007. 
Hashmi, M.Z., Shamseldin, A.Y. \& Melville, B.W. 2009. Statistical downscaling of precipitation: State-of-the-art and application of Bayesian multi-model approach for uncertainty assessment. Hydrol. Earth Syst. Sci. 6: 6535-6579.

Hassan, Z. \& Harun, S. 2012. Application of statistical downscaling model for long lead rainfall prediction in Kurau River catchment of Malaysia. Malaysia Journal of Civil Engineering 24(1): 1-12.

Hamidon, N., Harun, S., Malek, M.A., Ismail, T. \& Alias, N. 2015. Prediction $f$ paddy irrigation requirements using statistical downscaling and cropwat models: A case study from Kerian Irrigation Scheme in Malaysia. Jurnal Teknologi 76(1): 281-288.

Ismail, M., Suroto, A., Ismail, N.A. \& Latif, M.T. 2014. Surface ozone trend in major rice growing areas in Malaysia. Sains Malaysiana 43(3): 321-329.

Kwan, M.S., Fredolin, T.T. \& Juneng, L. 2013. Projected changes of future climate extremes in Malaysia. Sains Malaysiana 42(8): 1051-1058.

Lee, J.H.W. \& Lam, K.M. 2004. Environmental hydraulics and sustainable water management two volume set. Proceedings of the 4th International Symposium on Environmental Hydraulics \& 14th Congress of Asia and Pacific Division. International Association of Hydraulic Engineering and Research, 15-18 December, Hong Kong.

Mohsen, S., Zulkifli, Y., Milad, J. \& Fadhilah, Y. 2014. Development of generalized feed forward network for predicting annual flood (depth) of a tropical river. Sains Malaysiana 43(12): 1865-1871.

Semenov, M.A. \& Barrow, E.M. 2002. LARS-WG - A Stochastic Weather Generator for use in Climate Impact Studies. Hertfordshire: Rothamsted Research Harpenden.

Tukimat, N.N.A. \& Harun, S. 2013. The projection of future rainfall change over Kedah, Malaysia with the statistical downscaling model. MJCE 23: 67-79.
Tukimat, N.N.A. \& Alias, N.A. 2016. Assessment the potential of SRES scenario for Kuala Sala, Malaysia. IOSR-JMCE 13(3): 06-12.

Wilby, R.L. \& Dawson, C.W. 2007. SDSM 4.2 - A Decision Support Tool for the Assessment of Regional Climate Change Impacts. Lancaster University, Science Department, Environment Agency of England and Wales Department of Computer Science, Loughborough University, UK.

Yano, T., Aydin, M. \& Haraguchi, T. 2007. Impact of climate change on irrigation demand and crop growth in a Mediterranean environment of turkey. Sensors 7(10): 22972315 .

Nurul Nadrah Aqilah Tukimat*, Ahmad Saifuddin Othman, Saffuan Wan Ahmad \& Khairunisa Muthusamy

Faculty of Civil Engineering \& Earth Resources

Universiti Malaysia Pahang, 26300 Kuantan, Pahang Darul Makmur Malaysia

Nurul Nadrah Aqilah Tukimat*, Saffuan Wan Ahmad \& Khairunisa Muthusamy

Centre for Earth Resources Research \& Management (CERRM) Universiti Malaysia Pahang

26300 Kuantan, Pahang Darul Makmur

Malaysia

*Corresponding author; email: nadrah@ump.edu.my

Received: 16 February 2017

Accepted: 30 June 2017 